\title{
ATTITUDES AND EXPERIENCES OF WOMEN AND MINORITIES IN THE URBAN FORESTRYI ARBORICULTURE PROFESSION
}

\author{
By Michael R. Kuhns', Hope A. Bragg ${ }^{2}$, and Dale J. Blahna ${ }^{3}$
}

\begin{abstract}
In a study of urban forestry/arboriculture professionals in the United States, we found that love of trees and plants was most often listed as the reason for women and minorities entering the profession, followed closely by love of the outdoors. This order was reversed for white males. After enjoyment-related reasons, income/ employment potential was the most common reason for entering the profession for white males and minorities, but it was much less of a motivating factor for women. Satisfaction with the urban forestry profession was high and differed little among white males, females, and minorities. Satisfaction was higher for those in upper management, those with higher income, and those who entered the profession for enjoyment rather than income potential. Professional motivating factors that could be considered "selfless" ranked highest in importance, and "selfish" factors ranked lowest. Respondents generally disagreed that discrimination exists in the profession, with the level of disagreement varying depending on the type of discrimination and the respondents' gender/minority status.
\end{abstract}

Key Words. Urban forestry; arboriculture; ISA; SAF; minorities; women; gender; careers; diversity; discrimination.

In a recent paper (Kuhns et al. 2002), we reported that women and minorities are under-represented in the urban forestry/arboriculture profession in the United States, with $10 \%$ of urban forestry professionals women and 5\% minorities in 1996. Women generally were younger, better educated, had less time in their profession than white males, and most often held public or private nonprofit positions. Minorities were older and less educated than women or white males. A considerably higher proportion of minorities and lower proportion of females were in higher income categories (above US $\$ 50,000$ per year) than white males. Women were concentrated in mid-level and middle management positions, minorities in middle management, and white males in upper management. White males were more likely to be self-employed than were women or minorities.

These finding get at where women and minorities stand numerically within the profession but do not describe how they feel about their profession and why they are a part of it. Little research has been done on women and minorities in forestry, arboriculture, horticulture, and other "green industries," so there is little to summarize here. It is clear, though, that few women and minorities are in urban forestry professions, or forestry in general, and that their entry into these professions is lagging behind their entry into many other professions. Reasons for this lag are unclear, but based on past studies it may be due to prospects or reality of low income, discrimination, cultural preferences, or other factors.

Certainly discrimination in the forestry profession has existed in the not-so-distant past. The USDA Forest Service, an agency that now helps lead the way in encouraging inclusion of women and minorities in our profession, only 35 years ago tried to discourage women from being foresters. A 1967 Careers in Forestry brochure from the Forest Service (USDA-FS 1967) said of women in forestry:

There are stringent physical demands on an individual, and for this reason most of these positions are sought by men. Some women ... in forestry have pursued rewarding careers in forestry research, educational, or library work. Others interested in conservation and related fields have been trained in personnel, fiscal, or administrative management work ... rather than the actual technology of applied forestry.

If the leaders in forestry considered these things matterof-fact not so long ago, then perhaps such attitudes still persist or are thought to persist. An 18-year-old woman who saw that brochure in 1970 would be 50 years old today and might remember such attitudes. Though no data exist for urban forestry, Teeter et al. (1990) found that 59\% of women Society of American Foresters (SAF) members in the southeastern United States felt that women are not entering forestry because it is perceived as a profession for men. They also found that $65 \%$ of women felt that gender discrimination existed in their workplace, and $71 \%$ did not think that women have the same opportunities as men in the profession.

Minorities are so poorly represented in urban forestry and forestry in general that almost nothing is known of their experiences and attitudes within these professions. We found that only $5.3 \%(191$ of 3,615$)$ of respondents to a survey of urban forestry professionals were minorities (Kuhns et al. 2002) and that the membership of the Society of American Foresters (SAF) is only $1.6 \%$ minorities (SAF 2001). Several studies suggest minorities, especially African Americans, are less likely to belong to outdoor groups and visit outdoor areas due to economic, cultural, and discrimination-related barriers (Meeker et al. 1973; Taylor 1989; 
Blahna and Black 1993). These broad perceptions may also influence career choices, keeping some minorities away from outdoor-oriented careers.

In this paper, we will follow up on the description of the urban forestry profession's demographics as reported in Kuhns et al. (2002) by exploring attitudes and motivations of women and minorities regarding their urban forestry professions. This study was sponsored by the National Urban and Community Forestry Advisory Council (NUCFAC) to learn more about and to increase involvement of women and minorities in urban forestry professions.

\section{METHODS}

In 1996, we conducted a screening survey (to identify females and minorities) and an in-depth survey of urban forestry professionals in the United States using techniques described by Dillman (1978, 1999). This survey included all U.S.-resident members of the International Society of Arboriculture (ISA) and the Society of American Foresters (SAF) Urban Forestry Working Group, as well as state urban forestry and volunteer coordinators. The in-depth survey included all females and minorities we could identify $(\mathrm{N}=$ 527) plus a random sample of white males $(n=267)$. The detailed survey yielded 561 valid responses and a $75 \%$ response rate. Refer to Kuhns et al. (2002) for a complete description of the methods for this study and for descriptions of respondents' demographics. Data collected included work sector (public, private nonprofit, private for-profit), education, and income. Respondents also were asked about their reasons for entering the profession, job satisfaction, professional motivations, and discrimination, which will be described here. Note that since the entire female and minority population was used for the detailed survey, it is not appropriate to use inferential statistics-thus, we use descriptive statistics in this paper.

\section{RESULTS AND DISCUSSION Reasons for Entering the Profession}

Regardless of gender or minority status, enjoyment-related reasons were listed most often as the reason a respondent entered the urban forestry profession (Table 1). Love of the outdoors was the most common reason listed by white males, followed by love of trees/plants; this finding was reversed for women and minorities. After enjoyment, the most common reason for entering the profession for white males and for minorities was income/employment potential (both at $11 \%$ ); only $5 \%$ of females listed income/employment potential as a reason. Not surprisingly, median income was higher for those whose motivation for entering the profession was income/employment
(US\$38,938) than for those with other motivations (US\$33,000). Altruistic motivations (saving the planet and community service) were listed most often by women (22\%) and minorities (16\%) and least often by white males (8\%). Minorities were most likely and females were least likely to list having background/experience in the profession as a reason. Curiosity was listed as a reason by $5 \%$ of women and of minorities but only $1 \%$ of white males.

These results are somewhat comparable to those of Teeter et al. (1990), who found that women foresters were heavily motivated to enter the profession by altruism and a love of nature. The importance of enjoyment-related reasons that we found for entering the urban forestry profession may be somewhat comparable to Wright and Floyd's (1990) finding that 93\% of natural resource majors at The Ohio State University chose their major because of a strong interest in the area. Their second- and third-ranked reasons were career opportunities (71\%) and starting salaries (49\%), similar to our income/employment potential, though our numbers for that category were quite a bit lower. One difference between our findings and theirs is they found that women were more likely to select a natural resource major based on starting salary than men. These comparisons are somewhat suspect, of course, since Wright and Floyd were studying students and majors rather than professionals and careers.

\section{Satisfaction with the Profession}

General satisfaction with the urban forestry profession was high and differed little among white males, females, and minorities (Table 2). Minorities showed the highest mean satisfaction and women the lowest, but overall 95.9\% of respondents were satisfied or very satisfied. This is likely a somewhat skewed result, since our sample included current professionals only, not those who might have chosen to
Table 1. Motivations for entering the urban forestry profession shown as percentages within a gender or minority category (number of respondents in parentheses).

\begin{tabular}{llll}
\hline Motivation & $\begin{array}{l}\text { White male } \\
\mathrm{n}=220)\end{array}$ & $\begin{array}{l}\text { Female } \\
(\mathrm{N}=238)\end{array}$ & $\begin{array}{l}\text { Minority } \\
(\mathrm{N}=63)\end{array}$ \\
\hline Enjoyment reasons & $\mathbf{6 2 \% ( \mathbf { 1 3 7 } )}$ & $\mathbf{5 6 \% ( 1 3 3 )}$ & $\mathbf{5 1 \% ( 3 2 )}$ \\
Love of outdoors & $41 \%(91)$ & $26 \%(63)$ & $21 \%(13)$ \\
Love of trees, plants & $20 \%(44)$ & $28 \%(67)$ & $24 \%(15)$ \\
Enjoyment & $1 \%(2)$ & $1 \%(3)$ & $6 \%(4)$ \\
Altruistic reasons & $\mathbf{8 \% ( 1 8 )}$ & $\mathbf{2 2 \% ( 5 2 )}$ & $\mathbf{1 6 \% ( 1 0 )}$ \\
Save planet & $5 \%(11)$ & $11 \%(26)$ & $10 \%(6)$ \\
Service to community & $3 \%(7)$ & $11 \%(26)$ & $6 \%(4)$ \\
Other reasons & & & \\
Income/employment potential & $11 \%(24)$ & $5 \%(11)$ & $11 \%(7)$ \\
Background/experience in profession & $6 \%(13)$ & $4 \%(10)$ & $10 \%(6)$ \\
Family/friends in profession & $5 \%(10)$ & $4 \%(9)$ & $3 \%(2)$ \\
Curiosity & $1 \%(3)$ & $5 \%(11)$ & $5 \%(3)$ \\
Other & $7 \%(15)$ & $5 \%(12)$ & $5 \%(3)$ \\
\hline
\end{tabular}


Table 2. Answer to the question "In general, how satisfied are you with your profession?" Data include percentages within a gender/minority category, number of respondents in parentheses next to percentages, means, and standard deviations.

\begin{tabular}{|c|c|c|c|c|c|c|}
\hline Category & $\begin{array}{l}\text { Very } \\
\text { dissatisfied (1) }\end{array}$ & Dissatisfied (2) & Indifferent (3) & Satisfied (4) & $\begin{array}{l}\text { Very } \\
\text { satisfied (5) }\end{array}$ & Mean (SD) \\
\hline White male & $0.8 \%(2)$ & $2.5 \%(6)$ & $0.8 \%(2)$ & $39.3 \%(96)$ & $56.6 \%(138)$ & $4.48(0.72)$ \\
\hline Female & $0 \%(0)$ & $0.8 \%(2)$ & $3.9 \%(10)$ & $46.5 \%(118)$ & $48.8 \%(124)$ & $4.43(0.61)$ \\
\hline Minority & $0 \%(0)$ & $0 \%(0)$ & $1.4 \%(1)$ & $40.0 \%(28)$ & $58.6 \%(41)$ & $4.56(0.52)$ \\
\hline Overall & $0.4 \%(2)$ & $1.4 \%(8)$ & $2.3 \%(13)$ & $42.6 \%(238)$ & $53.3 \%(298)$ & $4.47(0.65)$ \\
\hline
\end{tabular}

leave the profession because they were dissatisfied. Still, it seems reasonable to assume that if many are dissatisfied and leave the profession, then some of that dissatisfaction would have registered here with those who had not yet left the profession. Our professional satisfaction findings for women are similar to those of Griffin (1993), who found that $89 \%$ of women natural resource professionals were glad they chose their profession.

Though general satisfaction with the urban forestry profession was high, some groups registered greater satisfaction than others. In particular, upper-level management showed considerably higher satisfaction (mean $=4.63)$ than entry-level (mean $=4.29$ ) or mid-level (mean $=4.32)$ employees. Similarly, those with higher income showed somewhat higher satisfaction; when annual income was above US $\$ 50,000$, mean satisfaction was $4.68(n=104)$, and when annual income was below US $\$ 35,000$, mean satisfaction was $4.37(n=267)$. Satisfaction varied little by education level, but reason for entering the profession seemed to matter somewhat. Those who entered the profession because of a love of trees, plants, or forestry were more satisfied, with a mean satisfaction of $4.58(n=156)$, than those who entered the profession for income potential, with a mean satisfaction of $4.20(\mathrm{n}=10)$. Though there were satisfaction differences, only 10 individuals, or $1.8 \%$, expressed any level of dissatisfaction with the profession (choices 1 or 2).

Respondents also indicated satisfaction by the level of their agreement with several statements dealing with professional benefits/rewards (Figure la-d). For Figures 1, 3 , and 4 , a six-point Likert scale is used, with $1=$ strongly disagree and $6=$ strongly agree. Though no neutral answer was presented in the questionnaire, 3.5 was the midpoint, so the means are presented as bars extending from this midpoint to more easily distinguish mean agreement from mean disagreement. On average, respondents slightly agreed that there was too much work for the pay, that they had the opportunity for promotion, and that their fringe benefits were good. Women were slightly more likely than white males or minorities to agree about too much work for the pay and benefits being good, and less likely to agree that they had the opportunity for promotion. Still, these differences were small. There was slight disagreement that there was no job security in the profession, with white males showing slightly stronger disagreement. Standard deviations for these means ranged from 1.29 to 1.49 , indicating a fairly wide range of responses. White males' answers on work for pay and on promotion varied the most (standard deviation nearly 1.5), and females' answers on benefits varied the least (standard deviation 1.29). Overall, this adds to the picture of a group of professionals who are fairly satisfied with their profession and the work they are doing, though adequate compensation for the work being done is an issue with some, especially women. This goes along with the finding described in the previous paragraph that making more money seems to increase overall professional satisfaction.

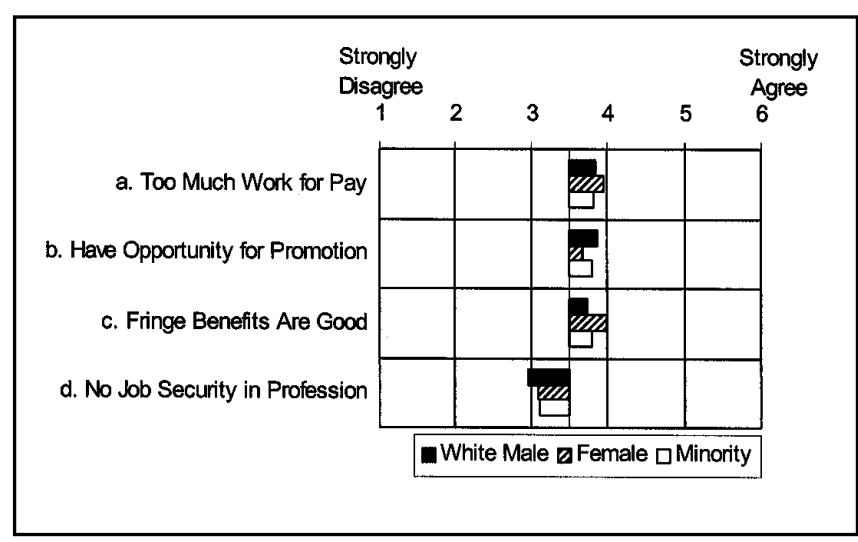

Figure 1. Job satisfaction as indicated by agreement with statements related to professional rewards/benefits (on left). Bars indicate mean level of agreement and originate at 3.5 for clarity ( 3.5 is the midpoint between the extremes of 1 = strongly disagree and $6=$ strongly agree). Means less than 3.5 indicate disagreement and greater than 3.5 indicate agreement. Standard deviations are not shown but ranged from 1.3 to 1.5 .

\section{Professional Motivations}

Respondents were asked to rate the importance of various motivating factors for them in their current profession on a five-point Likert-type scale ranging from $1=$ not important at all to $5=$ very important. Factors rated included job security, performance awards such as raises or bonuses, feelings of accomplishment, ability to advance, and ability to make a difference (Figure 2). Gender or minority status 


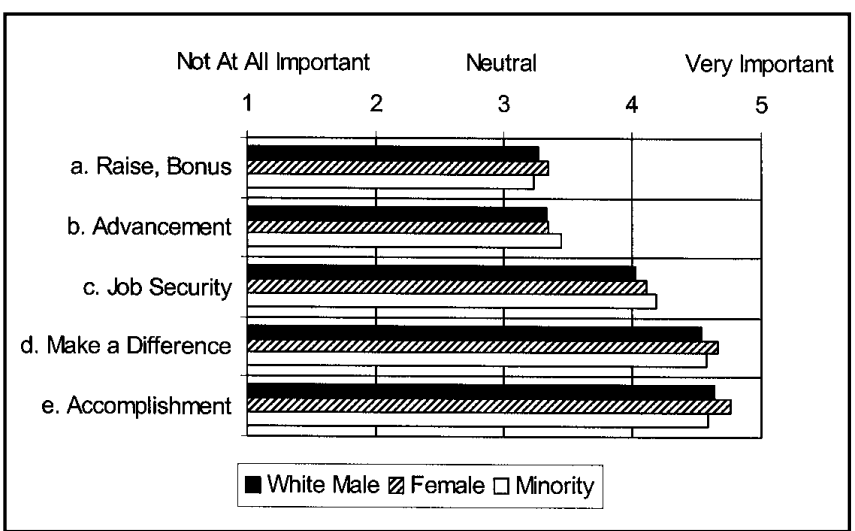

Figure 2. Answers to the question "How important are each of the following to you in your current profession?" Bars indicate means for five motivating factors (on left).

differences were minimal. For all groups, what could be called "selfless" motivations ranked highest in importance, and "selfish" motivations ranked lowest. Accomplishment or accomplishing something worthwhile was rated highest (means 4.59 to 4.76 ), with ability to make a difference close behind (means 4.54 to 4.66). Job security came next at just above 4 , and ability to advance and chances for a raise or bonus were ranked above neutral but much lower than the other factors. Griffin and Ehrenreich (1993) found that 60\% of women natural resource professionals listed "satisfying work" as the best part of their job-which is similar to our "accomplishments" or "making a difference," and only $11 \%$ listed money.

In comparing the results in Figure 2 with the data previously described in Figure 1, raises and bonuses aren't considered very important (Figure 2a), yet too much work for the pay is agreed to be something of an issue (Figure la). Professional advancement is considered weakly important (Figure 2b), and there is slight agreement that there is opportunity for promotion (Figure 1b). Finally, job security is considered very important (Figure 2c) but doesn't appear to be a major issue, since there is general agreement that there is good job security (disagreement that there is no job security; Figure 1d).

Respondents also indicated their agreement with various statements about certain professional values that could be considered motivational. These values included whether their profession is challenging, whether their purpose is clear, and whether they have a lot of freedom (Figure 3a-e). Gender or minority status differences again were minimal. Respondents strongly agreed that their profession was challenging, that what they do is important to them, and that their work is meaningful to them (Figure $3 a-c$ ), matching well with their expressions of the high importance of making a difference and accomplishment mentioned earlier (Figure $2 \mathrm{~d}-\mathrm{e}$ ). Agreement was strong, but less so, that their purpose in the profession is clear or that they have a lot of freedom (Figure 3d-e). Women were slightly less likely to agree that their purpose was clear and that they had a lot of freedom. Standard deviations were quite a bit lower compared to the reward/benefit statements mentioned earlier (Figure la-d), ranging from 0.79 to 0.99 for items $3 a-c$ and 1.00 to 1.23 for items $3 \mathrm{~d}-\mathrm{e}$. Urban forestry professionals appear to be in the profession more for the intangible rewards than for money and promotions

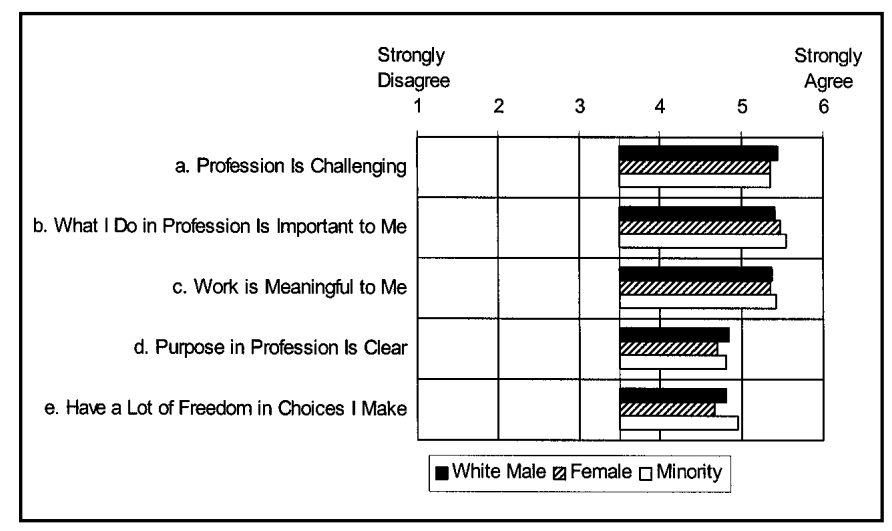

Figure 3. Agreement with statements related to professional values. Respondents were asked "How do you feel about your profession?" and answered by indicating their level of agreement with various statements (on left). Bars indicate mean level of agreement and originate at 3.5 for clarity ( 3.5 is the midpoint between the extremes of $1=$ strongly disagree and $6=$ strongly agree). Means less than 3.5 indicate disagreement and greater than 3.5 indicate agreement. Standard deviations are not shown, but ranged from 0.8 to 1.2 .

\section{Perceptions of Discrimination}

Figure 4 presents respondents' perceptions of discrimination in the profession by gender and minority status. We asked respondents to indicate how they felt about the profession by indicating their level of agreement with 36 statements about the profession and their perceptions and experiences. Seven gender- or minority-related statements and two disabilityrelated statement were scattered throughout the 36 .

Respondents generally disagreed with statements that discrimination exists in the profession, though the level of disagreement varied depending on the type of discrimination described and the respondent's gender/minority status. Respondents on average showed weak agreement that men and women are treated differently in the profession, with women showing the strongest agreement (Figure 4a). By itself this does not show discrimination against women, however, since the unequal treatment could be better or worse treatment. Statement $4 \mathrm{~b}$ more directly indicates discrimination against women, with its statement that women are 


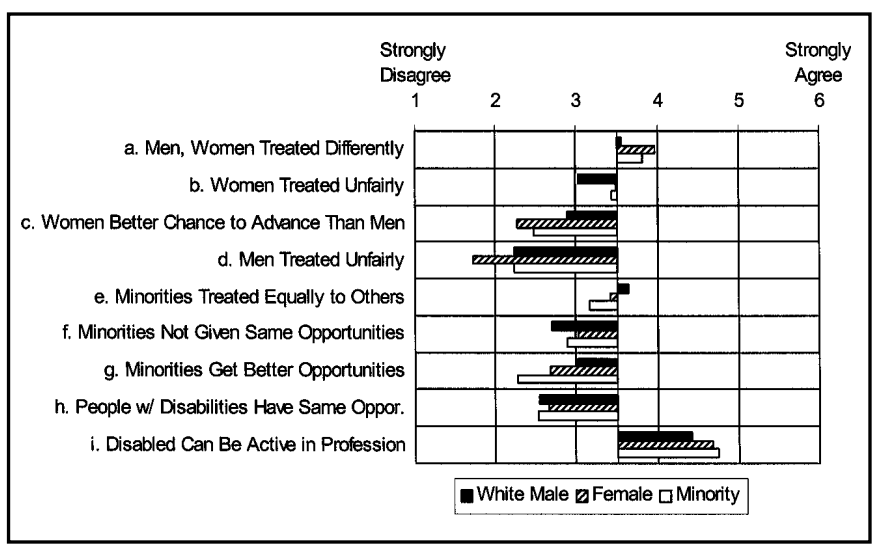

Figure 4. Agreement with statements related to discrimination in the profession. Respondents were asked "How do you feel about your profession?" and answered by indicating their level of agreement with various statements (on left). Bars indicate mean level of agreement and originate at 3.5 for clarity ( 3.5 is the midpoint between the extremes of $1=$ strongly disagree and $6=$ strongly agree). Means less than 3.5 indicate disagreement and greater than 3.5 indicate agreement. Standard deviations are not shown, but usually were around 1 to 1.3 and only exceeded 1.5 twice (for minorities for statements $b$ and $f$ ).

treated unfairly. There was mild disagreement with this statement among all groups, with women disagreeing only slightly (mean 3.49) and white men disagreeing slightly more strongly. Disagreement was much stronger that men are treated unfairly, with women disagreeing most strongly (Figure 4d). Comparing 4b and $4 d$, it appears that all groups perceive more discrimination against women than against men. Figure $4 \mathrm{c}$ is an indicator of perceptions of reverse discrimination, with its statement that women have better chances to advance in the profession than men. Disagreement was fairly strong with this statement, and was strongest with women and weakest with white males.

Figure $4 \mathrm{e}-\mathrm{g}$ refers to minorities and discrimination. There was weak disagreement by minorities and weak agreement by white males that minorities are treated equally to others in the profession (Figure 4e). Disagreement was stronger for all groups that minorities are not given the same opportunities or that they get better opportunities than others (Figure 4f, g).

Respondents also were asked to react to two statements about persons with disabilities in the profession (Figure 4h, i). Disagreement was moderately strong that those with
Table 3. Proportions and numbers of respondents indicating any agreement, strong agreement, or strong disagreement with several discrimination-related statements. Data presented include percentage agreement or disagreement within a gender/minority category and in parentheses the number giving a particular answer ( $N$ or $n$ ).

\begin{tabular}{|c|c|c|c|}
\hline Statement & $\begin{array}{l}\text { Any agreement } \\
\text { (answers } 4-6) \\
\%(\mathrm{~N} \text { or } \mathrm{n})\end{array}$ & $\begin{array}{l}\text { Strongly agree } \\
\text { (answer } 6) \\
\%(\mathrm{~N} \text { or } \mathrm{n})\end{array}$ & $\begin{array}{l}\text { Strongly disagree } \\
\text { (answer } 1 \text { ) } \\
\%(\mathrm{~N} \text { or } \mathrm{n})\end{array}$ \\
\hline \multicolumn{4}{|c|}{ Women generally treated unfairly in profession (see Figure 3b) } \\
\hline White male & $30.0 \%(68)$ & $2.2 \%(5)$ & $17.2 \%(39)$ \\
\hline Female & $44.2 \%(111)$ & $8.8 \%(22)$ & $10.8 \%(27)$ \\
\hline Minority & $42.4 \%(28)$ & $10.6 \%(7)$ & $15.2 \%(10)$ \\
\hline Overall & $38.0 \%(203)$ & $6.0 \%(32)$ & $13.5 \%(72)$ \\
\hline \multicolumn{4}{|c|}{ Men generally treated unfairly in profession (see Figure 3d) } \\
\hline White male & $8.5 \%(20)$ & $1.3 \%(3)$ & $41.7 \%(98)$ \\
\hline Female & $1.6 \%(4)$ & $0.8 \%(2)$ & $62.6 \%(152)$ \\
\hline Minority & $10.6 \%(7)$ & $6.1 \%(4)$ & $47.0 \%(31)$ \\
\hline Overall & $5.8 \%(31)$ & $1.7 \%(9)$ & $51.3 \%(275)$ \\
\hline \multicolumn{4}{|c|}{ Minorities not given same opportunities as others (see Figure 3f) } \\
\hline White male & $22.0 \%(49)$ & $3.1 \%(7)$ & $26.0 \%(58)$ \\
\hline Female & $26.8 \%(62)$ & $7.4 \%(17)$ & $16.9 \%(39)$ \\
\hline Minority & $31.8 \%(21)$ & $7.6 \%(5)$ & $30.3 \%(20)$ \\
\hline Overall & $25.4 \%(130)$ & $5.7 \%(29)$ & $21.9 \%(112)$ \\
\hline
\end{tabular}

disabilities have the same opportunities in the profession as those without disabilities (Figure 4h). However, agreement was moderately strong that those with disabilities can be active in the profession, with white males agreeing somewhat less strongly than females or minorities (Figure 4i).

The means in Figure 4a-g indicate generally mild disagreement or at most mild agreement that women and minorities are discriminated against in the profession. To investigate these differences in more detail, Table 3 presents the proportion and frequency for those who showed any agreement at all, strong agreement, and strong disagreement with three of the discrimination-related statements from Figure 4 (items b, d, and f). For example, Figure 4b indicated that women were near neutral to the idea that women are treated unfairly in the profession. However, Table 3 shows that $44 \%$ of women had at least some agreement and $8.8 \%$ strongly agreed with that statement, compared to $30 \%$ and $2.2 \%$ of white males. The proportion of females strongly disagreeing that men are treated unfairly was $63 \%$, while only $42 \%$ of white men disagreed with that statement. Similarly, a higher proportion of minorities than nonminorities indicated some agreement and strong agreement that minorities are discriminated against, though interestingly, minorities also were more likely to strongly disagree that they are not given the same opportunities.

Though perceptions of discrimination in the urban forestry profession are fairly weak, the thoughts and attitudes of those perceiving discrimination are interesting 
and may prove useful. Table 4 presents all discriminationrelated comments that were written on the questionnaires by gender/minority status of the respondent. It seems notable that, given the number of respondents, there are fairly few comments $(n=35)$ about discrimination and that many comments are fairly positive, indicating increasing opportunities and the ability for persons to excel if they are qualified. Women's comments indicating discriminatory behavior referred to incidents or behaviors involving both colleagues and clients. Several comments also referred to perceptions of reverse discrimination involving both minorities and women. Finally, several of the negative comments addressed lack of women and minority participation in the urban forestry profession in general, rather than discrimination against those who are in the profession.

A much higher level of perceived sexual discrimination in forestry in general was reported by Teeter et al. (1990) than we found here, with $65 \%$ of southern women foresters believing that sex discrimination existed in their place of work. Of course, their results were for women foresters in general, rather than for urban foresters, were localized to the southern United States, and were obtained 14 years ago. Griffin and Ehrenreich (1993) asked women natural resource professionals who subscribed to the journal Women in Natural Resources about a particularly direct form of sexual discrimination, sexual harassment. They found that $71 \%$ of their respondents had personally experienced sexual harassment in the workplace, though only $33 \%$ felt it was a problem for them. Though we did not ask these questions, this appears to be a much higher level of perceived discrimination than we found in urban forestry. The lower median incomes for women compared to white males and minorities reported by us in Kuhns et al. (2002) may be a sign of discrimination against women; however, we also found that women had less experience as indicated by time in the profession (a mean of 11 years for females versus 16 years for minorities and 19 years for white males).

\section{CONCLUSIONS}

We have described some of the attitudes and motivations of urban forestry professionals, particularly those of women and minorities. We hope that this information, along with the demographic and income information described in Kuhns et al. (2002), can enlighten the profession in terms of what women and minorities are experiencing and how they feel about it. It is clear, though, that differences between these groups and white males are subtle and relatively minor. It also looks as though women and minorities like the profession and find it rewarding. Discrimination against those currently in the profession does not appear to be a major factor keeping women and minorities out. If we want to increase their participation in the profession, the trick may be getting the word out that the urban forestry profes- sion is worth considering, using current women and minority professionals who are happy in the profession both as examples for prospective professionals and mentors for incoming professionals. It also is necessary to get them into the degree programs that are the entry points into the profession, a difficult task when so many women and minorities avoid science-oriented fields (Leslie et al. 1998). Perhaps we could consider hiring from beyond the ranks of traditional forestry graduates by broadening qualifications to allow for other natural resource-oriented degrees that draw more women, such as environmental studies. The greatest help, it seems, will be to continue to hire qualified women and minorities whenever possible to provide mentors and role models for future generations of women and minority urban foresters.

\section{LITERATURE CITED}

Blahna, D.J., and K.S. Black. 1993. Racism: A concern for recreation resource managers?, pp 111-118. In Gobster, P.H. (ed.). Managing Urban and High-Use Recreation Settings. USDA Forest Service GTR NC-163.

Dillman, D.A. 1978. Mail and Telephone Surveys: The Total Design Method. Wiley-Interscience, New York, NY. 1999. Mail and Internet Surveys: The Tailored Design Method. John Wiley and Sons, New York, NY.

Griffin, K.A. 1993. Women in Natural Resources subscribers: Part one. Women Nat. Resourc. 15(2):9-10.

Griffin, K.A., and D.L. Ehrenreich. 1993. Women in Natural Resources survey: Part two. Women Nat. Resourc. 15(3):28-33.

Kuhns, M.R., H.A. Bragg, and D.J. Blahna 2002. Involvement of women and minorities in the urban forestry profession. J. Arboric. 28(1):27-34.

Leslie, L.L., G.T. McClure, and R.L. Oaxaca. 1998. Women and minorities in science and engineering: A life sequence analysis. J. Higher Educ. 69(3):239-276.

Meeker, J.W., W.K. Woods, and W. Lucas. 1973. Red, white, and black in the national parks. N. Am. Rev. 258:3-7.

Society of American Foresters. 2001. Report on demographics of organization. Personal communication. SAF, Bethesda, MD.

Taylor, D.E. 1989. Blacks and the environment: Toward an explanation of the concern and action gap between blacks and whites. Environ. Behav. 21(2):175-205.

Teeter, L.D., L. Thara Bhai, and J.C. Bliss. 1990. Perspectives of women foresters in the South. Women Nat. Resourc. $12: 20-23$.

USDA Forest Service. 1967. Careers in Forestry. USDA Forest Service Misc. Publ. No. 49, p. 3.

Wright, P.A., and D.W. Floyd. 1990. Some pertinent gender and racial differences at Ohio State University. Women Nat. Resourc. 12:31-34. 
Table 4. Discrimination-related comments written on the questionnaire by respondents by gender/minority status. Comments are organized in order of generally positive (little discrimination or things not too bad and getting better), generally negative (significant discrimination), or neutral (general comment or difficult to classify).

\section{Comments by females (all were white; no comments from female minorities)}

Generally positive

- I think opportunities for women are increasing daily.

- A competent, self-confident person will be treated like one; a person always trying to make excuses for their inabilities or inadequacies will probably find it easy to be discriminated against because they are discriminating against themselves.

- As a woman with a disability, I have been extremely sensitive to the potential for "real" or "perceived" favoritism or discrimination. My findings are that qualifications are the determining factors, not race, sex, or disability.

- Discrimination is a straw man set up to excuse personal failure.

- [There are opportunities] for minorities to advance in this profession, but only if the employer supports their effort to learn English.

Generally negative

- The tree department in our city is still "good old boyish." They aren't ready for women yet, but someday ...

- There is a bias against hiring women for "heavy" landscaping or maintenance, but bias towards women for "high-end" gardening and professional design/sales, horticulture work that involves more thinking, writing, and talking.

- The "good ol' boy" network is alive and well within the profession.

- It's a man's profession.

- If I wanted part of another sales rep's territory, all I had to do was sleep with him.

- Mostly verbal abuse and unneeded comments that I just ignore and/or live with.

- I've found there are some folks with a mindset "I'll never change" and unfortunately this is a lot of times younger men.

- I have seen many double standards within situations in 14 years, mostly on the local level; state level is okay.

- Clients can be a problem; they are sexist.

- [It is] frustrating to be a woman in the business particularly because of unequal treatment and the rumors that are inevitable.

- I was assumed to be a lesbian.

- I was assumed to be a secretary or the boss's daughter or wife; if I got along with male co-workers, I'm assumed to be having an affair with them.

- I've had to work harder and be better to be judged as my male counterpart's equal.

- Minorities get the low-paying jobs for all the landscape jobs.

- Minorities lower the wage scale.

- $\quad$ Minorities] are given preferential treatment.

- There are not a significant number of minorities being trained or who choose this profession. We have trained nearly 200 foresters as data collectors for our inventory, and there have been about six blacks, three Asians, a few Hispanics, and no one with disabilities.

Generally neutral

- What minorities? I don't experience this.

- I do not know very many minorities or disabled persons in urban forestry. Or women for that matter.

Comments by white males

Generally positive

- $\quad$ [Women] are treated the same, equal.

Generally negative

- Women and minorities as of my knowledge do not proceed in this occupation. It is too labor intensive. There are exceptions to this, but they are few.

- I feel it is the other way around. Minorities get used and aren't compensated enough.

- Women seem to have an edge for consideration in promotions in this profession (management positions, educational and research promotions). The gender pendulum has swung, or so it seems in [state].

- $\quad[$ Minorities] are treated better sometimes.

Generally neutral

- There is no such thing as a level playing field, and motivation to accomplish anything must start from within. If [the] desired goal is truly worth attaining, the struggle to achieve it is at best secondary.

- I am disappointed that any survey in this day and age focuses so much attention on race, sex, and physical ability.

- [I] know of only one or two women in the trade.

- If there are few minorities in urban forestry, it is because there are few minorities studying the discipline that leads to this profession.

- [The] tendency is for introverted people to gravitate to forestry to get away from people; most jobs are people jobs; there is no "hermit in the woods" existence.

Comments by minorities

Generally neutral

- White, male, balding, dominant. 
Acknowledgments. Support for this project came from the National Urban and Community Forestry Advisory Council, Utah State University Extension, and the Utah Agricultural Experiment Station, Logan, UT 84322-4810. Approved as UAES journal paper no. 7553.

\author{
${ }^{1 *}$ Associate Professor \\ ${ }^{2}$ Extension Forestry Assistant (former) \\ Department of Forest, Range, and Wildlife Sciences \\ Utah State University \\ Logan, UT 84322-5230, U.S.
}

\author{
${ }^{3}$ Associate Professor \\ Department of Environment and Society \\ Utah State University \\ Logan, Utah 84322-5215, U.S.
}

Résumé. Dans une étude auprès des professionnels de la foresterie urbaine aux États-Unis, nous avons découvert que l'amour des arbres et des plantes était le critère le plus souvent évoqué comme étant la raison pour laquelle les femmes et le minorités entraient dans cette profession, suivi de très près par l'amour des espaces extérieurs. Cet ordre était inversé pour les hommes de race blanche. Après les raisons relatives à la joie, le potentiel salarial par rapport à l'emploi était le motif le plus habituel pour joindre cette profession pour les hommes blancs et les minorités, mais par contre cela était un facteur moindre de motivation chez les femmes. La satisfaction envers la profession de la foresterie urbaine était la plus élevée pour ceux qui étaient dans l'échelon le plus élevé de gestion, ceux avec les salaires les plus élevés et pour ceux qui étaient entrés dans la profession plus par intérêt que pour le potentiel salarial. Les facteurs de motivations professionnelle qui pouvaient être considérés comme « désintéressés » se classaient de manière plus élevée dans l'ordre d'importance et ceux plus « égoïstes » de manière plus basse. Les répondants n'étaient généralement pas d'accord qu'il existait une discrimination au sein de la profession, et ce avec un degré de désaccord variant selon le type de discrimination ainsi que selon le genre et le statut minoritaire des répondants.

Zusammenfassung. In einer amerikanischen Studie über professionelle Arboristen in Städten fanden wir heraus, dass die Liebe zu Bäumen und Pflanzen der meistgelistete Grund, gefolgt von der Liebe für die Arbeit draussen für Frauen und Minderheiten war, um diesen Beruf zu ergreifen. Dieses Ergebnis wurde revidiert von den weißen Männern. Nach Freude an der Arbeit waren Einkommensund Anstellungspotential die meistgenannten Gründe für weiße Männer und Minderheiten, diesen Beruf zu ergreifen, Aber für Frauen war das kein motivierender Grund. Die Befriedigung durch den Job war hoch und wenig differenziert zwischen den weißen Männern, Frauen und Minderheiten. Die Befriedigung war größer in den höheren Einkommensklassen und für diejenigen, die den Beruf eher für Freude an der Arbeit als an den Einkommenschancen ergriffen haben. Professionelle motivierende Faktoren könnten in erster Linie Selbstlosigkeit und als letztes Selbstsüchtigkeit sein. Die Teilnehmer der Umfrage stimmten nicht zu, dass in diesem Beruf Diskriminierung herrscht, mit unterschiedlichen Abstufungen in Abhängigkeit von dem Typ der Diskriminierung und dem Status der Herkunft.

Resumen. En un estudio de profesionales dasónomos urbanos en los Estados Unidos, encontramos que el gusto por los árboles y plantas fue con frecuencia indicado como la razón por la cual las mujeres y minorías entran en la profesión, seguida de cerca por el gusto a los espacios abiertos. Este orden fue inverso para los hombres blancos. Después de las razones de disfrute, el potencial ingresos/ empleo fue la razón más común para conocer la profesión para hombres blancos y minorías, pero este factor de motivación es mucho menor para las mujeres. La satisfacción con la profesión de la dasonomía urbana fue mayor y difirió poco entre hombres blancos, mujeres y minorías. La satisfacción fue mayor para los presupuestos mayores, con más altos ingreso, y quienes se enteraron de la profesión por disfrute antes que por ingreso potencial. Los factores de motivación profesional que podrían ser considerados "selfless" estuvieron desde las importancia más alta y factores "selfish" de la más baja. Los encuestados generalmente no estuvieron de acuerdo en que exista discriminación en la profesión, con el nivel de desacuerdo variando dependiendo al tipo de discriminación y al estatus género/minoría de los encuestados. 